\title{
Have Male and Female Careers Converged?
}

Les carrières salariales des hommes et des femmes : quelle convergence sur longue période?

Fabienne Berton, Jean-Pierre Huiban and Frédérique Nortier Ribordy

\section{OpenEdition}

\section{Journals}

Electronic version

URL: http://journals.openedition.org/travailemploi/6303

DOI: $10.4000 /$ travailemploi.6303

ISSN: 1775-416X

\section{Publisher}

DARES - Ministère du Travail

\section{Printed version}

Date of publication: 15 December 2013

Number of pages: 99-114

ISSN: 0224-4365

\section{Electronic reference}

Fabienne Berton, Jean-Pierre Huiban and Frédérique Nortier Ribordy, « Have Male and Female Careers Converged? », Travail et Emploi [Online], Hors-série | 2013, Online since 01 January 2014, connection on 19 April 2019. URL : http://journals.openedition.org/travailemploi/6303 ; DOI : 10.4000/ travailemploi.6303 


\title{
Have Male and Female Careers Converged?"
}

\author{
Fabienne Berton ${ }^{(* *)}$, Jean-Pierre Huiban ${ }^{(* *)}$, Frédérique Nortier Ribordy ${ }^{(* * *)}$
}

\begin{abstract}
This paper asks whether male and female careers have converged over the long run in France, and if so in which sense. Data from the EIC (Échantillon Inter-régimes de Cotisants) 2001 panel are analysed to construct the careers of French private-sector employees. Two cohorts are considered, the first composed of individuals born in 1946 and the second of those born in 1962. Male and female careers are found to be very different in the first cohort. However, in the second cohort the careers of both sexes are both more similar to each other and different from those observed for men in the older cohort. Careers are now frequently long, but also more often interrupted for both sexes. There continues to be a wage gap between men and women, but also a significant rise in the heterogeneity of careers within each sex.
\end{abstract}

Over the past thirty years, labour-market careers have undergone substantial modifications. The appearance of mass unemployment and insecure employment, the development of flexible working, macroeconomic instability, and the changing nature of female labour supply have all led the canonical model of the labour-market career (which was typically masculine, of continuous improvement with few or no interruptions) to be called into question.

The aim of the current paper, which brings together researchers and managers in the French compulsory supplementary pension scheme (see Berton, Huiban, Nortier, 2009), is to provide a detailed analysis of labour-market careers in the private sector, including any interruptions and discontinuities, in order to evaluate the impact of changes in regulations on the size of retirement pensions. The first original aspect of this paper is the data used to carry out this evaluation. In general, work in this area has used DADS(1) data, which only provides information on labourmarket spells in which the individual received a salary while working in the private sector. We here appeal to data from the EIC 2001 (the Échantillon Inter-régimes de Cotisants; see Box 1), an administrative database set up by the Drees ${ }^{(2)}$ in order to

(*) Article published in French in Travail et emploi, $\mathrm{n}^{\circ}$ 125, janvier-mars 2011

(**) Lise CNRS, Cnam; fabienne.berton@cnam.fr

$(* * *)$ Jean-Pierre Huiban died suddenly on the $16^{\text {th }}$ of June

2013 at the age of 58. He was Research Professor at the ALISS research centre of the Inra, and associated Professor of Economics at the University of Paris-Est Créteil, in the Erudite research centre. His co-author Frédérique Nortier Ribordy and his wife Fabienne Berton dedicate this work to him.

$(* * * *)$ Agirc-Arrco; fnortier-ribordy@agirc-arrco.fr

(1) Déclarations annuelles de données sociales.

(2) Drees: Direction de la recherche, des études, de l'évaluation et de la santé, which is a joint entity of the Social Affairs Ministry. provide information on the pension rights acquired under different retirement schemes: individuals appear in this database when they contribute to one of the compulsory pension schemes (Colin, El Mekradui de Freitas, Michaudon, 2004). This panel data allows us to better understand individual careers on the labour market, as it includes both salaried employment and periods spent out of the labour market which count towards the individual's pension (unemployment where the individual receives benefits, illness etc.).

We here propose an original methodological approach (see Boxes 2 and 3). Existing work has largely appealed to two different methods. The first consists of the estimation of wage equations (MINCER, 1974), that is the empirical relationship between the individual's wage and their education and labour-market experience, as well as other variables such as their sex, industry and firm size. Other work (see BRIARD, 2007, for example) is based on different analytical techniques, where the careful analysis of the consequences of labourmarket events (such as unemployment or illness) is used in order to come up with typologies of labourmarket careers. These two approaches complement each other. The use of typologies allows a better analysis of heterogeneity in labour-market careers by putting greater emphasis on the phenomena of continuity and rupture as opposed to individual observable characteristics. Alternatively, separate wage equations for different groups can be estimated as another way of capturing the different types of labour-market careers.

The current paper is written in this spirit. The first part introduces our main hypothesis of a convergence on the labour market of the careers followed by men and women, which results mainly from a break in trends between 1975 and 1985. The second part then presents the data which we will use. Our 
results appear in the third part of the article, and are based on the joint application of the two approaches mentioned above: the estimation of a wage equation for the whole sample, followed by a typological analysis. We then reconsider the different classes that result from the latter by re-estimating separate wage equations for each of the identified groups. Finally, our conclusion underlines our main result: the convergence of male and female labour-market careers in an original model, which is different from the standard model of male careers in the post-war period.

\section{The Hypothesis of the Convergence of Male and Female Labour-Market Careers}

The question we address here is at the crossroads of three separate fields of research: those on the determination of (mostly male) wages (MAGNAC, Roux, 2009), changes in professional mobility (DE Larquier, Remillon, 2008; Amossé, Ben Halima, 2010) where wages do not always appear as the central variable, and gender wage gaps (Meurs, Ponthieux, 2006) which in general is not couched in the terms of careers but rather inequality or discrimination.

While the term labour-market career is often used to refer strictly to movements in the individual's position in the wage hierarchy (LoLLIVIER, PAYEN, 1990), this usage is insufficient for the work that we wish to carry out here. We consider that an individual career is made up of a succession of different states, ranging from inactivity to paid employment. As such, careers consist not only of a succession of employment episodes of varying length in one or more firms, with their associated wages, but also of episodes reflecting career interruptions. The literature on wage determination over the career is voluminous (see the surveys in WILLIS, 1986, and CARD, 1999). However, wages are only one component of the career question that we wish to address here. This wage component will be all the more important the greater the share of paid employment in the individual's career. However, recent trends have been towards a rising preponderance of episodes of inactivity (in the wage sense), for a number of different reasons: unemployment, illness, temporary or permanent retirement (voluntary or otherwise), or other changes in labour-force status. As career breaks have become less rare, and arguably even normal (or at least frequent), their analysis has started to occupy an increasing central position alongside the traditional investigation of wages.

The separation of men and women is a useful starting point for the complex question of labour-market careers. This allows us first to describe the elements that lie behind the careers of a given generation of individuals, and then understand how and why these careers have changed over time, and in particular to consider the hypothesis of male and female career convergence. In this spirit, BRIARD (2007) underlines, for both the pre and post babyboom generations, how the male model of long and uninterrupted careers contrasts with that of shorter female careers with early exit from the labour market. For the younger generations, longer careers with more frequent interruptions have become more prevalent for both sexes. For the cohorts entering the labour market after 1975, female careers have improved at the same time as male careers have deteriorated. The slowdown in wages at the beginning of the 1980s hit men born after the beginning of the 1960s particularly hard, with their starting wages no longer being higher than men from older cohorts. Women, on the other hand, continued to enjoy secular rises in starting wages from one cohort to another (NorTiER, Rass, 2006).

This research thus finds that there has been a transformation in male and female careers, and suggests a number of lines of inquiry. In general, the socio-economic context has evolved. In particular, between the 1960s and the 1980s there have been a number of changes which have led to a break in the general form of careers:

- structural change in the active population and in jobs, such as the general rise in the level of education, the switch to the service sector and the increasing presence of women on the labour market and female jobs;

- the end of the practice of indexing of wages to prices in 1982, and the rising percentage of workers who earn the minimum wage (Demailly, LE Minez, 1999);

- the appearance of mass unemployment and the development of under-employment and involuntary mobility.

One first effect of these changes has been rising job insecurity. New workers seem to have become increasingly good substitutes for older workers (GIVORD, MAURIN, 2003), and there has been a general rise in insecurity. On the labourdemand side, LeCLAIR and Roux (2000) note that $19 \%$ of paid work hours in 2000 were carried out by workers who stayed less than one year with their employer. LeCLAIR and Roux (2007) further underline the increase in short-term (under one year) jobs, and propose two interpretations: the employers' demand for employment flexibility and their use as a probationary period to evaluate the employees' productivity in the job. BeHAGHEL (2003) provides a more nuanced explanation of this phenomenon by underlining the decline in long-term labour contracts upon hiring, rather than existing contracts being broken: job 
insecurity, measured by the annual transition rate from employment to non-employment, has risen considerably in France, but is concentrated among certain types of workers, the least-qualified and the recently-hired.

A second effect concerns the general form of labour-market careers, where a large literature has emphasised a structural break in careers over the 1975-1985 period (Debrand, Privat, 2002). In particular, the gaps between age groups have widened, and the age at which earnings are the highest has increased. For individuals born between 1930 and 1954, starting wages rose systematically from one generation to the next; for those born between 1955 and 1975, who entered the labour market in the middle of the 1970s, the gaps in starting wages have been considerably reduced, except for those with university degrees (BUCHINSKY, FougĖre, Kramarz, 1998), so that the career differences between these two broad cohorts are not only explained by the accumulation of human capital. The returns to education have fallen in recent years, at the same time as the general level of qualifications in the labour force has risen. Overall, the gaps in earnings between different levels of training and education have broadly remained stable.

\section{The Selection of Two Generations and the Characteristics of their Careers}

The dataset we use (EIC 2001) is organised by generation (see Box 1). The generations for which sufficient information is available range from 1946 to 1970 (referring to the birth dates of the individuals whose careers are analysed here).

\section{The Choice of Two Generations: 1946 and 1962}

We contrast individuals from two generations. Those born in 1946 are the oldest represented in the database. These individuals entered the labour market in the socio-economic environment of the 1960s, well before the various breaks underlined in the literature mentioned above. In this respect the careers of the 1946 generation are representative of those at the beginning of the baby boom. At the other end of the spectrum, individuals in the 1962 generation are the youngest for whom we observe sufficient labour-market experience ( 23 years). This is the first generation which was thoroughly exposed to the effects of the breaks above, as individuals here entered the labour market at the

\section{Box 1}

\section{The 2001 EIC Data and the Construction of Wages}

Our analysis here comes from the 2001 Échantillon Inter-régimes de Cotisants (EIC 2001) dataset. This survey, which was set up to evaluate the pension rights acquired by those active in the labour market with respect to compulsory pension schemes, is an individual-level panel. The Drees collected information on earnings, yearly acquired pension rights, and any periods of unemployment or illness. This information was obtained from all of the compulsory pension schemes, Unédic (which provides unemployment benefits), Insee (the national statistics agency), the National Accounts and the Ministry of Defense.

The EIC covers individuals born in October of even-numbered years to allow it to be matched to data from the DADS panel. The 2001 sample includes individuals aged between 31 and 67 on the $31^{\text {st }}$ of December 2001 (i. e. born between 1934 and 1970). One generation out of four is sampled, and $2.67 \%$ of the individuals by sampled generation. Our analysis sample here covers individuals who have at least one period of registered contributions to either Arrco (1) or Agirc (2) and who were not retired on the 31 st December 2001 (that is the generations from 1946 to 1970 ). This sample covers 135000 individuals and over 2 million individual/year observations.

One difficulty here is the measurement of managerial earnings. We have two sources of data in this respect: the DADS, which does not appear in the EIC until 1976, and the declarations from the basic compulsory pension scheme, which only refer to the portion of earnings under the social-security ceiling up to 1999 . However, $14 \%$ of workers, principally managers, have earnings over this ceiling during the period under consideration. We estimate managerial earnings using information on the annual pension rights acquired under the Agirc regime. Both the level and the changes of annual gross earnings are similar across the two data sources. In the end we decided to use the gross annual earnings figures estimated from the pension-rights data.

Hours of work (daily, monthly or annual) are unusable in this database as they are incomplete in the EIC data. As such, we are not able to distinguish between full-time, part-time and temporary work.

The EIC data does not contain any information on education. We calculate the age of entry into the labour force as that corresponding to the first year with four validated quarters in terms of social security contributions. The age of average entry rises from 18 and half for the 1946 generation to almost 22 for that of 1970 , reflecting the increase in both the time spent in education and that to fully enter the labour market.

(1) Association du régime de retraite complémentaire des salariés.

(2) Association générale des institutions de retraite des cadres. 
beginning of the 1980s. In order to compare the two generations, we limit our analysis to individuals aged between 16 and 39 .

\section{The Thirteen States of Labour- Market Careers}

The first stage here is to characterise individual careers. Individuals are observed each year, and their labour-market situation is defined by one exclusive labour-force status. The succession of these annual statuses constitutes the individual's career. We appeal to three types of information to define the annual statuses: the number of quarters contributed as a wage earner, the number of quarters validated as career interruptions such as unemployment or illness, and years with any validated quarter. Taking these together allows us to define a number of different statuses:

-Total inactivity before labour-market entry or during the career (no validated or contributed quarters);

- Partial activity (one to four quarters validated with perhaps one quarter contributed, $i$. e. unemployment or illness for part or all of the year with at most one quarter of paid work and/or inactivity);

- Non-private sector employment (public sector and self-employment);

- Private sector employment. In this last case, there are two types of situations: either activity is continuous over the year, with four contributed quarters, or it is discontinuous without another labour-force status being identified, with one to three quarters contributed. Gross annual earnings in both cases are compared to the overall earnings distribution in the respective generation, regardless of the actual length of individual labour supply.

The SITU variable defined in Table 1 represents our taxonomy of the different exclusive individual labour-force statuses which we will use to construct careers.

\section{Career Developments Over Two Generations}

\section{Descriptive Statistics and Flow by Age}

The statistics in Table 2 describe the differences between men and women, and how these have changed between the two generations. Average gross annual earnings have risen over time, as has the share of women and managers. We can also see that the percentage of workers who have experienced a career interruption (due to illness or unemployment), either in the year in question or at any time in their career, has increased, leading to a fall in average seniority.

Female average gross annual earnings have risen relative to those of men, although they remain lower. The dispersion of female earnings (as measured by the standard deviation) has fallen, while that of men has risen somewhat. The share of managers has increased more for women than for men between

Table 1: Definition of the Thirteen Individual Annual Labour-Force Statuses Used to Describe Careers (SITU)

\section{Pre-entry into the labour market}

Y Before the start of labour-market activity (education, inactivity or training scheme)

\section{Paid employment only}

N Paid employment only with gross annual earnings insufficient to contribute four quarters over the year

P Paid employment only with gross annual earnings in the bottom 20 per cent and four quarters contributed

D Paid employment only with gross annual earnings in the $21^{\text {st }}$ to $45^{\text {th }}$ centile and four quarters contributed

$\mathrm{T} \quad$ Paid employment only with gross annual earnings in the $46^{\text {th }}$ to $60^{\text {th }}$ centile and four quarters contributed

Q Paid employment only with gross annual earnings in the $61^{\text {st }}$ to $85^{\text {th }}$ centile and four quarters contributed

C Paid employment only with gross annual earnings above the $85^{\text {th }}$ centile and four quarters contributed

\section{Career interruptions in the year}

E Paid work with unemployment and/or illness in the year and four quarters validated

Unemployment and/or illness all the year and four quarters validated

Non-private sector activity

A

Employment other than private sector with four quarters validated (possibly with unemployment and/or illness)

Other employment situations with four quarters contributed (possibly in a number of different sectors and possibly with unemployment and/or illness)

Loose link with the labour market or inactivity

\begin{tabular}{|c|c|}
\hline X & Between one and three quarters validated other than as an employee \\
\hline I & No quarters validated \\
\hline
\end{tabular}




\section{Box 2 \\ Wage Equations and Typological Analysis}

Our research here combines two approaches: the econometric estimation of individual wage equations and the construction of a typology of careers using a classification method.

\section{Wage equations}

The estimation of wage equations is one of the staple techniques in labour economics. The simplest form corresponding to the notion of an individual labour-market career consists in estimating the relationship between $w_{i,}$, the earnings of individual $i$ in year $t$, to EXP ${ }_{i t}$, the individual's labour-market experience, with $\varepsilon_{i t}$ representing an error term whose specification depends on the choice of estimator (see Box 3 for details of variable construction):

$$
\log w_{i t}=\beta_{0}+\beta_{1} E X P_{i t}+\beta_{2} E X P_{i t}^{2}+\varepsilon_{i t}
$$

The use of a quadratic form for experience here allows us to test for a possible concave form here, where wages stop rising with labour-market experience after $-\frac{\beta_{1}}{2 \beta_{2}}$ years. This equation supposes that the only variable which explains earnings is labour-market experience. This is obviously an unconvincing hypothesis (LolLIVIER, PAYEN, 1990). Other observable (years of education, sex, job characteristics, individual ability, etc.) or unobservable characteristics will affect earnings, which may or may not reflect discrimination (with respect to sex or religion, for example). The omission of these variables, if they are correlated with the explanatory variables introduced into the regression, will lead to omitted-variable bias.

There are two ways of dealing with this problem. The first is to introduce other measurable characteristics into the wage equation, again estimated over the whole population:

$$
\log w_{i t}=\beta_{0}+\beta_{1} E X P_{i t}+\beta_{2} E X P_{i t}^{2}+\sum_{k=3}^{K} \beta_{k} x_{k i t}+\varepsilon_{i t}
$$

There are many such "augmented" wage equations in the literature (WILLIS, 1986; CARD, 1999). It should be noted that these additional variables only rarely refer to events that occur over the individual's labour-market career, such as career interruptions. This approach has therefore only partially taken into account such discontinuities. The effect of the latter on earnings is also not completely captured by the inclusion of individual fixed effects into the estimated regression. The use of the EIC data allows us to explicitly introduce a number of variables characterising labour-market interruptions, whether they are annual or observed at a given point in time over the career.

A second angle of attack is to try to reduce the impact of unobserved heterogeneity by estimating separate wage equations on sub-groups which are considered to be more homogeneous with respect to the question under consideration here, that is the form of the individual's labour-market career. How should these different groups be constituted? The estimation of separate wage equations for men and women is a first answer. We therefore estimate the following equation separately by gender:

$$
\log w_{i t}=\beta_{0}+\beta_{1} E X P_{i t}+\beta_{2} E X P_{i t}^{2}+\beta_{3} E D U_{i}+\beta_{4} M A N_{i t}+\beta_{5} \text { CAINTY }_{i t}+\beta_{6}{C A I N T C A_{i}}+\varepsilon_{i t}
$$

The earnings of individual $i$ in year $t$ are here supposed to depend on their labour-market experience, but also on the job type (the dummy variable $M A N$, which distinguishes managers and non-managers), the number of years of education $E D U$, and two variables indicating a career interruption, either in the year of the earnings observation $\left(C_{\left.A I N T Y_{i t}\right)}\right.$ or at any time in the individual's career $\left(C A I N T C A_{i}\right)$. The separate estimation allows us to compare the estimated coefficients and yields far more information than the simple insertion of a dummy sex variable in a pooled wage equation.

Individual heterogeneity is however not confined to observable variables which can be introduced into the regression, such as sex. Methods do exist which can help to control for this heterogeneity, some of which we will use below, such as the introduction of an individual fixed effect. However, heterogeneity may change over time, especially as a result of the career interruptions which occur at different moments in the labour-market career. The use of the method of typological analysis, in which changes in status play a crucial role, will complement the econometric analysis.

\section{Typological analysis}

We have two aims in constructing a typology of careers: first, the general description of these labour-market careers and how they have changed from one generation to another, and second the estimation of wage equations for types of workers who are a priori more similar.

To discriminate adequately between labour-market groups, a career typology has to satisfy a number of objectives: in particular, it has to distinguish between groups in terms of the order of different labour-force statuses and the time spent in each status. Labour-market histories are classified according to their successive states (GRELET, 2002). The trajectory is described by carrying out a multiple correspondence analysis (MCA) on the labour-force statuses at different ages/years. A classification is then carried out on the first 150 factors, which represent over $80 \%$ of the total inertia of the cloud of points. We use the classification method recommended for large samples (NAKACHE, ConfAIS, 2005), which consists in linking together two separate methods:

- two non-hierarchical mean-shift clusters. These are then interacted to produce strong forms, with 350 classes resulting; - a hierarchical ascendant classification (HAC) is then carried out on the strong forms. We use the Wald classification criterion, which maximises inter-class inertia and minimises intra-class variance.

This classification is carried out separately for the 1946 and 1962 generations. We find that the majority of the identified classes appear in both generations, although their composition and relative importance do change over time. This method produces a typology of twelve classes for each of the two generations. 
the two generations under consideration, as has the share experiencing career interruptions in the year in question or over the career (which does not only correspond to maternity leaves). This produces a lower accumulated seniority figure for women than for men, and a larger gap between accumulated seniority and labour-force experience for women.

\section{Box 3 \\ Variable Descriptions}

The SITU variable reflecting the individual's labour-force status in a given year, which is used for the classification and the creation of the time diagrams, has already been defined in the text. The other variables which appear in the descriptive statistics and the regressions are as follows:

- Earnings: average annual gross earnings in 2007 Euros;

- Manager: a dummy variable $(M A N)$ for being a manager or not;

- The estimated number of years of education $(E D U)$, given by the estimated age on entering the labour market (four quarters validated) minus the legal school-leaving age (14 or 16);

- Career interruption in the year of observation $\left(\right.$ CAINTY $\left._{i t}\right)$, defined as the presence of a career interruption of six months in the year of observation;

- Career interruption over the career (CAINTCA $\left.A_{i}\right)$ defined as the presence of a career interruption of six months, for whatever reason, at any time in the career to date (between ages 16 and 39);

- Labour market experience $\left(E X P_{i t}\right)$, measured as the maximum presence in the labour market from the difference between the year of the first job (four quarters validated) and the year of observation;

- Seniority or effective experience $\left(S E N_{i t}\right)$, measured at the year of observation. This is given by the measure of potential labour-market experience as defined above (EXP) minus the number of years in which the individual "disappears" from the dataset. An individual who is present from 1981 to 1985 , then from 1991 to 1995 will have, in 1995, 15 years of experience and 10 years of seniority.
The thirteen annual labour-force statuses that we defined above allow us to examine the global change in careers between the two generations. We present the results using flow by age, which yield a visual representation of the distribution for the generation at each date (which corresponds to given age for the individuals of each generation), and which thus reveals the changes in this distribution over time between the different statuses (see Table 1).

Figure 1 shows flow by age for the careers of men and women in the 1946 and 1962 generations between the ages of 14 and 39 .

The careers of men and women in the 1946 generation are very different. We see for men a spike in inactivity at age 19-20 which corresponds to military service (which we do not see for men in the 1962 generation), and for women different inactivity spikes between the ages of 20 and 30 corresponding to maternity, which we do not find for the women born in 1962. Compared to men, the careers of women in the 1946 generation are marked by the movement into inactivity, low earnings and various intermediate statuses between inactivity and employment.

For the 1962 generation, we first note the lengthening of the period before the first job which corresponds to a greater amount of time spent in education and training. We also see for both sexes an increase in the prevalence of years which mix both employment and unemployment and/or illness. Last, the difference between the careers of men and women fades noticeably over time. The share of inactivity amongst women of the 1962 generation is markedly lower, and is close to that for men. Women are somewhat more likely to be found in lower-wage jobs, to have career interruptions in the year of observation, and to be found in intermediate statuses between inactivity and employment. This visual impression can be confirmed by econometric analysis.

Table 2: Descriptive Characteristics of the Two Generations (Between Ages 16 and 39) by Sex

\begin{tabular}{|c|c|c|c|c|c|c|c|}
\hline & $\begin{array}{c}\text { Average } \\
\text { annual } \\
\text { earnings } \\
\text { (Standard } \\
\text { Deviation) }\end{array}$ & $\begin{array}{l}\text { Interruption } \\
\text { in the year } \\
(\% \text { of workers })\end{array}$ & $\begin{array}{l}\text { Interruption } \\
\text { in the career } \\
(\% \text { of workers })\end{array}$ & $\begin{array}{c}\text { Average } \\
\text { experience } \\
\text { accumulated } \\
\text { at age } 39 \\
\text { (years) }\end{array}$ & $\begin{array}{c}\text { Average } \\
\text { seniority } \\
\text { accumulated } \\
\text { at age } 39 \\
\text { (years) }\end{array}$ & $\begin{array}{c}\text { Managers } \\
(\% \text { of workers })\end{array}$ & $\begin{array}{c}\text { Gender } \\
\text { share in the } \\
\text { generation } \\
\text { (\% of workers) }\end{array}$ \\
\hline \multicolumn{8}{|l|}{ Men } \\
\hline $\begin{array}{l}\text { 1946 Generation } \\
\mathrm{N}=8187\end{array}$ & $\begin{array}{c}16890 \\
(11631)\end{array}$ & 1.4 & 83.5 & 20.0 & 19.4 & 10.5 & 54.2 \\
\hline $\begin{array}{l}\text { 1962 Generation } \\
\mathrm{N}=10922\end{array}$ & $\begin{array}{c}20788 \\
(13404)\end{array}$ & 5.7 & 89.5 & 18.6 & 17.3 & 11.7 & 51.2 \\
\hline \multicolumn{8}{|l|}{ Women } \\
\hline $\begin{array}{l}\text { 1946 Generation } \\
\mathrm{N}=6912\end{array}$ & $\begin{array}{c}10860 \\
(20645)\end{array}$ & 1.6 & 83.3 & 19.5 & 17.2 & 3.3 & 45.8 \\
\hline $\begin{array}{l}\text { 1962 Generation } \\
\mathrm{N}=10391\end{array}$ & $\begin{array}{c}14160 \\
(11628)\end{array}$ & 6.6 & 91.4 & 18.4 & 16.4 & 6.1 & 48.8 \\
\hline
\end{tabular}

Source: Drees, EIC 2001 and calculations from Cnam-Inra-Agirc/Arrco. 
Figure 1: Flow by Age of Male and Female Labour-Market Careers for the 1946 and 1962 Generations from Ages 14 to 39

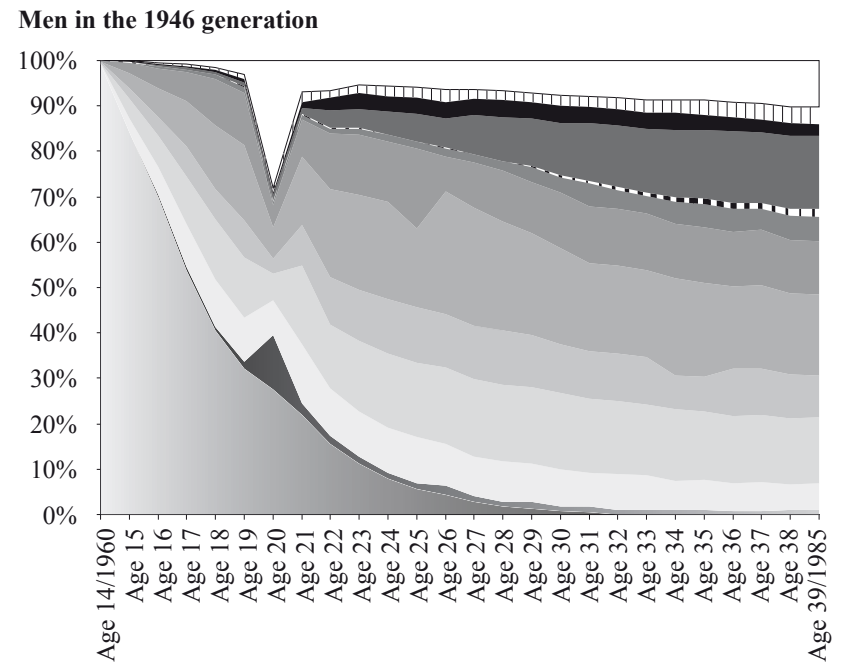

Women in the 1946 generation

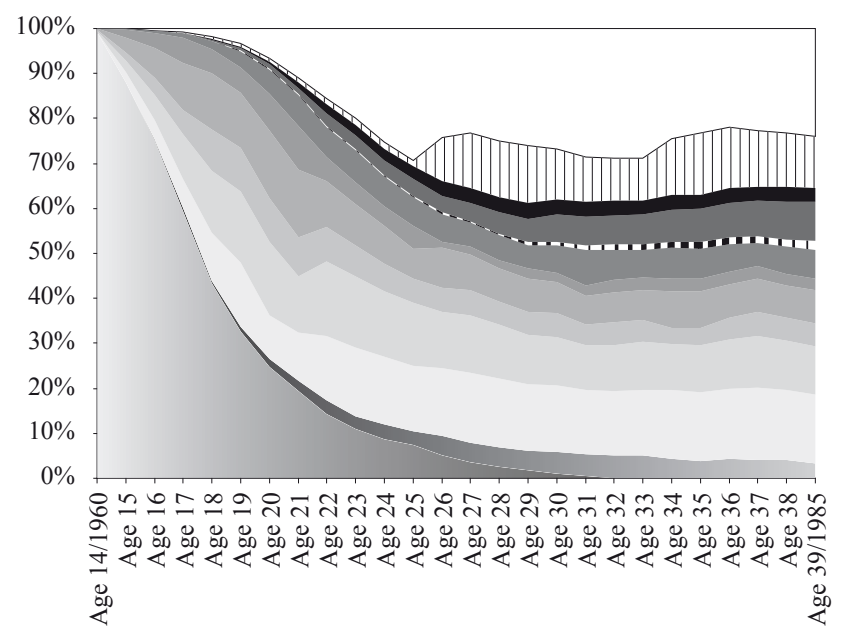

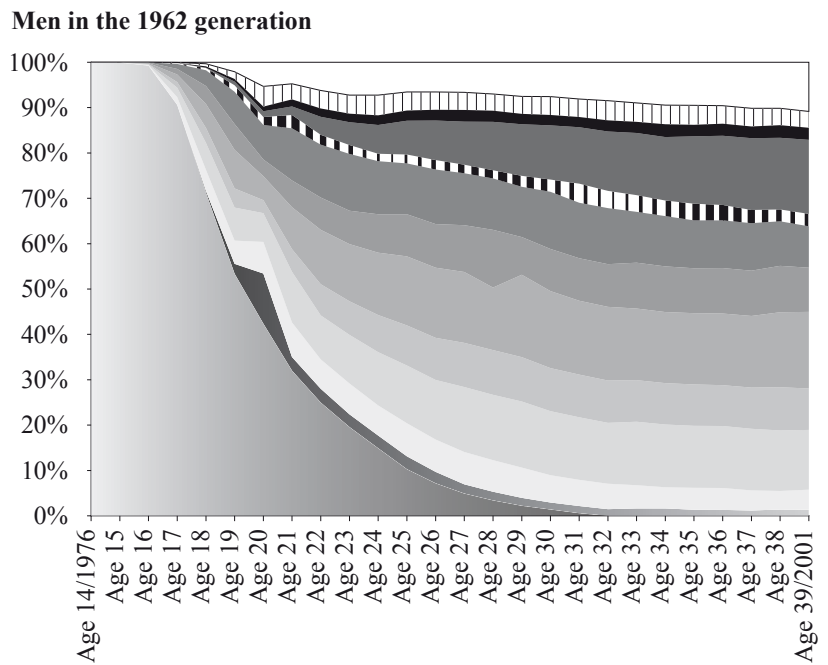

Women in the 1962 generation

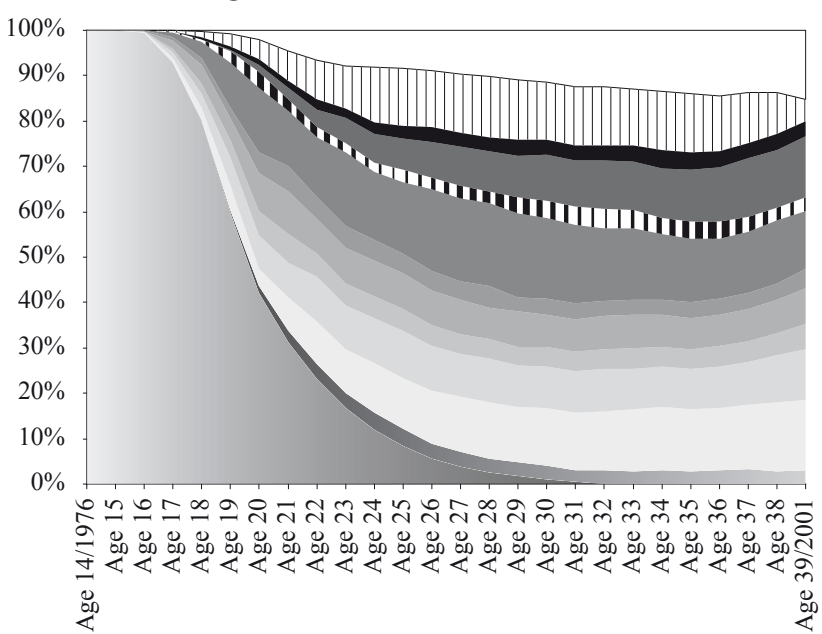

Source: Drees, EIC 2001 and calculations from Cnam-Inra-Agirc/Arrco.

Table 3: Earnings Equations by Sex for the 1946 and 1962 Generations, Model 1

\begin{tabular}{|c|c|c|c|c|c|c|c|c|}
\hline & \multicolumn{4}{|c|}{1946 Generation } & \multicolumn{4}{|c|}{1962 Generation } \\
\hline & \multicolumn{2}{|c|}{ Within } & \multicolumn{2}{|c|}{ Hausman-Taylor } & \multicolumn{2}{|c|}{ Within } & \multicolumn{2}{|c|}{ Hausman-Taylor } \\
\hline & Men & Women & Men & Women & Men & Women & Men & Women \\
\hline$E X P$ & $\begin{array}{c}0.164 \\
(0.001)\end{array}$ & $\begin{array}{c}0.102 \\
(0.007)\end{array}$ & $\begin{array}{c}0.164 \\
(0.001)\end{array}$ & $\begin{array}{c}0.103 \\
(0.007)\end{array}$ & $\begin{array}{c}0.086 \\
(0.002)\end{array}$ & $\begin{array}{c}0.031 \\
(0.008)\end{array}$ & $\begin{array}{c}0.087 \\
(0.002)\end{array}$ & $\begin{array}{c}0.032 \\
(0.008)\end{array}$ \\
\hline$E X P^{2}$ & $\begin{array}{l}-0.0033 \\
(0.00004)\end{array}$ & $\begin{array}{l}-0.0047 \\
(0.00025)\end{array}$ & $\begin{array}{l}-0.0033 \\
(0.00004)\end{array}$ & $\begin{array}{l}-0.0046 \\
(0.00024)\end{array}$ & $\begin{array}{l}-0.0020 \\
(0.00007)\end{array}$ & $\begin{array}{c}-0.00029 \\
(0.00030) n s\end{array}$ & $\begin{array}{l}-0.0021 \\
(0.00007)\end{array}$ & $\begin{array}{l}-0.00030 \\
(0.00030) n s\end{array}$ \\
\hline$M A N$ & $\begin{array}{c}0.553 \\
(0.006)\end{array}$ & $\begin{array}{c}1.400 \\
(0.055)\end{array}$ & $\begin{array}{c}0.553 \\
(0.006) \\
\end{array}$ & $\begin{array}{c}1.503 \\
(0.054) \\
\end{array}$ & $\begin{array}{c}0.498 \\
(0.008)\end{array}$ & $\begin{array}{c}0.873 \\
(0.043) \\
\end{array}$ & $\begin{array}{c}0.548 \\
(0.008)\end{array}$ & $\begin{array}{c}1.031 \\
(0.042) \\
\end{array}$ \\
\hline$E D U$ & & & $\begin{array}{c}0.066 \\
(0.001) \\
\end{array}$ & $\begin{array}{c}-0.051 \\
(0.011)\end{array}$ & & & $\begin{array}{c}0.010 \\
(0.003)\end{array}$ & $\begin{array}{c}-0.024 \\
(0.014) \mathrm{ns}\end{array}$ \\
\hline CAINTY & $\begin{array}{c}-0.522 \\
(0.010)\end{array}$ & $\begin{array}{c}-0.030 \\
(0.056) n s\end{array}$ & $\begin{array}{c}-0.522 \\
(0.010)\end{array}$ & $\begin{array}{l}-0.007 \\
(0.055) n s\end{array}$ & $\begin{array}{c}-0.225 \\
(0.008) \\
\end{array}$ & $\begin{array}{c}0.249 \\
(0.029)\end{array}$ & $\begin{array}{c}-0.236 \\
(0.007)\end{array}$ & $\begin{array}{c}0.260 \\
(0.028)\end{array}$ \\
\hline CAINTCA & & & $\begin{array}{c}-0.101 \\
(0.010)\end{array}$ & $\begin{array}{c}-0.978 \\
(0.090)\end{array}$ & & & $\begin{array}{r}-0.127 \\
(0.022) \\
\end{array}$ & $\begin{array}{c}-0.649 \\
(0.124) \\
\end{array}$ \\
\hline Adjusted R ${ }^{2}$ & 0.7246 & 0.0553 & & & 0.2104 & 0.0456 & & \\
\hline Individuals & 8112 & 6864 & 8112 & 6864 & 10711 & 10217 & 10711 & 10217 \\
\hline Observations & 136500 & 98320 & 136500 & 98320 & 153780 & 139212 & 153780 & 139212 \\
\hline
\end{tabular}

Note: The variables EXP, EXP2 and EDU are considered as endogenous. All regressions include year dummies (estimates not shown). Standard errors are in parentheses. All of the estimated coefficients are significant at the one per cent level, except those indicated by $n s$.

Source: Drees, EIC 2001 and calculations from Cnam-Inra-Agirc/Arrco. 


\section{Wage Equations: Potential Experience and Real Seniority}

Table 3 shows the results from the estimation of separate wage equations by sex, for the 1946 and 1962 generations. Career activity covers the 19621985 period for the former and the 1978-2001 period for the latter. We choose the Within estimator from the various estimation options available (CORNWELL, RUPERT, 1988), together with the instrumental variables estimator ${ }^{(3)}$ of HAUSMAN and TAYLOR (1981) in order to estimate coefficients on time-invariant variables. The estimations also include time dummies (whose estimated coefficients are not shown here). Other estimators, such as generalised least squares (individual random effects) are not employed here as they are rejected by the Hausman test.

For the 1946 generation, the signs and sizes of the estimated coefficients are consistent with those previously found in the literature, and more generally with the predictions from the theoretical model. The estimated coefficient on experience is positive and that on experience-squared is negative. The coefficient on manager is positive, while those on career interruptions are negative. Education is estimated to have a significantly positive effect on earnings.

The comparison between men and women careers uncovers a number of differences. The annual growth in men's wages is noticeably larger, while managerial status brings a larger wage premium for women. The impact effect of a career interruption (in the same year) is larger for men, but the permanent effect (over all of the career) is larger for women. Last, the return to education differs sharply by sex: it is positive for men but negative for women. It should be underlined however that the education variable is only imperfectly measured here, and effectively picks up late entry onto the labour market. We could therefore be faced with considerable measurement error, which may well vary by sex. As such, caution is required in the interpretation of these education coefficients.

The results for the 1962 generation show a global reduction in the differences between male and female careers, with a convergence towards a profile that is notably different from that for men in the 1946 generation. The different coefficients on the experience variables are all much smaller, with the value of another year of labour-market experience for a man in the 1962 generation being smaller than that for a woman in the 1946 generation. The earnings premium from a managerial position stays roughly the same for men, but has fallen for women. The return to education drops sharply for men and becomes insignificant for women. Last, the effect

(3) See for example Behaghel (2006) for details of this approach. of career interruptions also changes: career interruptions in the year of observation become less negative, while those over the whole career remain large and negative, especially for women.

These results overall suggest that labour-market careers, as summarised in wage equations, have evolved towards something that is different from male careers in the 1946 generation, where experience played such a key role. More generally, the good fit of the wage equation for men in the 1946 generation is much worse for women of the same generation, and for both sexes in the 1962 generation. The theoretical model underlying these equations therefore does a good job for men in the earlier cohort, but not for anyone else. We therefore modify the specification, and replace experience (as defined by the date of entry into the labour market) by seniority or effective experience in employment. This substitution yields different, and more convincing, results (see Table 4). The estimated coefficients on this new variable are different from those on experience in Table 3, and the estimated coefficients on the other control variables in the wage equation also change.

The estimated coefficients for men in the 1946 generation change the least, except for the careerinterruption variables, whose coefficients are somewhat smaller in size (with part of their initial impact now being captured by the effective experience variable). The estimated coefficients for women in the 1946 generation change radically. The estimated coefficient on effective seniority is more than double that previously estimated on experience, and is larger than that estimated for men. More surprisingly, the estimated coefficient on education also rises very significantly and becomes larger than that in the male wage equation. The results for the 1962 generation confirm the effect of this new seniority variable. The returns to seniority fall only little between 1946 and 1962 for men and rise for women; this is also the case for the returns to education.

The comparison of these estimation results suggest that one of the key differences between male and female careers, and those of the 1946 and 1962 generations, is not so much the dynamics of continuous presence in employment, but rather the effect of career discontinuities. Men in the 1946 generation had accumulated an average of 20.07 years of potential experience at age 39, of which 19.42 years of effective seniority. The situation of women is different in this generation: 19.47 years of potential experience for 17.24 years of effective seniority. All of these values are lower in the 1962 generation, but the gap between the two indicators is larger. The average male career at age 39 consists of 18.63 years of experience, but only 17.28 years of effective seniority. The male situation in the 1962 generation is thus similar to that of women 
in the 1946 generation. At the same time, the situation of women has changed: in the later generation they have 18.36 years of potential experience but only 16.26 years of effective seniority. Rather than the relationship of these variables to earnings evolving, it is the change in their average values which is behind the observed modifications in the models of labour-market careers. A year of experience continues to have the same effect on earnings, as long as it is effective seniority. However, the increasing presence of career interruptions has created a growing gulf between potential experience (measured from the date of labour-market entry) and effective seniority. Meurs, Pailhe and Ponthieux (2008) address a different question, but come to the same conclusion regarding the replacement of potential by actual labour-market experience.

\section{Different Types of Career}

The typological analysis reveals twelve classes in the 1946 generation. All of these classes are also found in the 1962 generation, with two exceptions: one class of the 1946 generation disappears while a new class appears for the 1962 generation. Comparing these twelve classes across the 1946 and 1962 generations, we note the rising number of workers who have long careers in the private sector: the percentage concerned rises from $53.2 \%$ for the generation born in 1946 to two-thirds (66.7\%) of the generation born in 1962.(4) Women increasingly have long careers: $56.5 \%$ of women in the
1946 generation and $62.5 \%$ of those in the 1962 generation, in line with the finding in Meurs and Ponthieux (2006) that women aged between 30 and 50 have careers that are increasingly full from one generation to another.

We retain seven of these twelve classes for more detailed analysis. These seven classes are chosen according to three criteria: the percentage of the population covered, the corresponding percentage of women in the generation, and the percentage of women in the class. The characteristics of the classes are presented in Table 5 and the corresponding earnings equations in Table 6 . The analysis of these classes reveals four major differences between the generations of 1946 and 1962: at the two extremities of the earnings scale, the growth in the prevalence of careers with low earnings but also of those with high earnings, the growth of careers characterised by some form of insecurity, and the decline in the "classic" model of the female labour-market career of the 1950s and 1960s.

\section{The Growth in Long Careers with Low Earnings}

Long careers with low earnings (under the $45^{\text {th }}$ centile of the earnings distribution) were already present in the 1946 generation (see Figure 3). However, the importance of this class rose in the 1962 generation, partly due to the growth in the numbers in the $\mathrm{C} 3$ class in the population (from 13.2 to $14.6 \%$ ) and partly due to the appearance of a new related class $(\mathrm{C} 2)$ with even more sharply-defined low earnings (under the $20^{\text {th }}$ centile of the earnings

Table 4: Earnings Equations by Sex for the 1946 and 1962 Generations, Model 2

\begin{tabular}{|c|c|c|c|c|c|c|c|c|}
\hline & \multicolumn{4}{|c|}{1946 Generation } & \multicolumn{4}{|c|}{1962 Generation } \\
\hline & \multicolumn{2}{|c|}{ Within } & \multicolumn{2}{|c|}{ Hausman-Taylor } & \multicolumn{2}{|c|}{ Within } & \multicolumn{2}{|c|}{ Hausman-Taylor } \\
\hline & Men & Women & Men & Women & Men & Women & Men & Women \\
\hline SEN & $\begin{array}{c}0.170 \\
(0.001)\end{array}$ & $\begin{array}{c}0.278 \\
(0.007)\end{array}$ & $\begin{array}{c}0.170 \\
(0.001)\end{array}$ & $\begin{array}{c}0.287 \\
(0.007)\end{array}$ & $\begin{array}{c}0.130 \\
(0.002)\end{array}$ & $\begin{array}{c}0.328 \\
(0.008)\end{array}$ & $\begin{array}{c}0.134 \\
(0.002)\end{array}$ & $\begin{array}{c}0.339 \\
(0.008)\end{array}$ \\
\hline$S E N^{2}$ & $\begin{array}{l}-0.0038 \\
(0.00004)\end{array}$ & $\begin{array}{l}-0.0034 \\
(0.00024)\end{array}$ & $\begin{array}{l}-0.0038 \\
(0.00004)\end{array}$ & $\begin{array}{l}-0.0035 \\
(0.00025)\end{array}$ & $\begin{array}{l}-0.0029 \\
(0.00007)\end{array}$ & $\begin{array}{l}-0.0078 \\
(0.00032)\end{array}$ & $\begin{array}{r}-0.0030 \\
(0.00071)\end{array}$ & $\begin{array}{l}-0.0080 \\
(0.00031)\end{array}$ \\
\hline$M A N$ & $\begin{array}{c}0.547 \\
(0.006) \\
\end{array}$ & $\begin{array}{c}1.171 \\
(0.054)\end{array}$ & $\begin{array}{c}0.568 \\
(0.005)\end{array}$ & $\begin{array}{c}1.258 \\
(0.052) \\
\end{array}$ & $\begin{array}{c}0.482 \\
(0.008)\end{array}$ & $\begin{array}{c}0.736 \\
(0.043) \\
\end{array}$ & $\begin{array}{c}0.522 \\
(0.008)\end{array}$ & $\begin{array}{c}0.873 \\
(0.041) \\
\end{array}$ \\
\hline$E D U$ & & & $\begin{array}{c}0.068 \\
(0.001)\end{array}$ & $\begin{array}{c}0.150 \\
(0.010)\end{array}$ & & & $\begin{array}{c}0.045 \\
(0.002)\end{array}$ & $\begin{array}{c}0.166 \\
(0.013)\end{array}$ \\
\hline CAINTY & $\begin{array}{r}-0.497 \\
(0.010)\end{array}$ & $\begin{array}{c}0.414 \\
(0.055)\end{array}$ & $\begin{array}{c}-0.508 \\
(0.010)\end{array}$ & $\begin{array}{c}0.448 \\
(0.053)\end{array}$ & $\begin{array}{c}-0.189 \\
(0.007)\end{array}$ & $\begin{array}{c}0.300 \\
(0.028)\end{array}$ & $\begin{array}{c}-0.197 \\
(0.007)\end{array}$ & $\begin{array}{c}0.314 \\
(0.028)\end{array}$ \\
\hline CAINTCA & & & $\begin{array}{c}-0.062 \\
(0.010)\end{array}$ & $\begin{array}{c}-0.710 \\
(0.085)\end{array}$ & & & $\begin{array}{c}-0.070 \\
(0.021)\end{array}$ & $\begin{array}{c}-0.512 \\
(0.121)\end{array}$ \\
\hline Adjusted $\mathbf{R}^{2}$ & 0.7232 & 0.0877 & & & 0.2263 & 0.0583 & & \\
\hline Individuals & 8112 & 6864 & 8112 & 6864 & 10711 & 10217 & 10711 & 10217 \\
\hline Observations & 136500 & 98320 & 136500 & 98320 & 153780 & 139212 & 153780 & 139212 \\
\hline
\end{tabular}

Note: The variables SEN, SEN 2 and EDU are considered as endogenous. All regressions include year dummies (estimates not shown). Standard errors are in parentheses. All of the estimated coefficients are significant at the one per cent level.

Source: Drees, EIC 2001 and calculations from Cnam-Inra-Agirc/Arrco.

(4) Note that these percentages refer to classes that are not identical across the two generations, although they are similar. 
Table 5: Descriptive Statistics for the Seven Retained Classes

\begin{tabular}{|c|c|c|c|c|c|c|c|c|}
\hline Typological class & Generation & $\begin{array}{c}\text { Average } \\
\text { annual } \\
\text { earnings } \\
\text { (Standard } \\
\text { Deviation) }\end{array}$ & $\begin{array}{c}\text { Interruption } \\
\text { in the year } \\
(\% \text { of workers })\end{array}$ & $\begin{array}{c}\text { Interruption in } \\
\text { the career } \\
\text { (\% of workers) }\end{array}$ & $\begin{array}{l}\text { Experience } \\
\text { (Seniority) } \\
\text { (years) }\end{array}$ & $\begin{array}{c}\text { Managers } \\
(\%)\end{array}$ & $\begin{array}{c}\text { Women } \\
(\%)\end{array}$ & $\begin{array}{l}\text { Percentage } \\
\text { of class in the } \\
\text { generation } \\
(\% \text { of workers })\end{array}$ \\
\hline \multirow{2}{*}{$\begin{array}{l}\text { C2: Long Career } \\
\text { with very low } \\
\text { earnings }\end{array}$} & $\begin{array}{l}1946 \\
N=0\end{array}$ & / & I & / & I & / & I & / \\
\hline & $\begin{array}{c}1962 \\
N=955\end{array}$ & $\begin{array}{l}10703 \\
(8004)\end{array}$ & 5.3 & 91.6 & $\begin{array}{c}19.6 \\
(18.2)\end{array}$ & 0.7 & 79.7 & 4.5 \\
\hline \multirow{2}{*}{$\begin{array}{l}\text { C3: Long Career } \\
\text { with low earnings }\end{array}$} & $\begin{array}{c}1946 \\
N=1997\end{array}$ & $\begin{array}{c}12717 \\
(5762) \\
\end{array}$ & 1.0 & 83.5 & $\begin{array}{l}22.1 \\
(21.8)\end{array}$ & 0.4 & 33.2 & 13.2 \\
\hline & $\begin{array}{c}1962 \\
N=3108\end{array}$ & $\begin{array}{c}15153 \\
(5645)\end{array}$ & 4.1 & 88.2 & $\begin{array}{c}20.3 \\
(19.5)\end{array}$ & 1.0 & 41.5 & 14.6 \\
\hline \multirow{2}{*}{$\begin{array}{l}\text { C5: Long Career } \\
\text { with high earnings }\end{array}$} & $\begin{array}{c}1946 \\
N=1426\end{array}$ & $\begin{array}{l}18209 \\
(7171)\end{array}$ & 0.7 & 74.5 & $\begin{array}{c}20.9 \\
(20.9)\end{array}$ & 1.9 & 23.4 & 9.4 \\
\hline & $\begin{array}{c}1962 \\
N=2961\end{array}$ & $\begin{array}{l}22787 \\
(9148)\end{array}$ & 2.7 & 84.8 & $\begin{array}{c}19.8 \\
(19.3)\end{array}$ & 9.0 & 31.2 & 13.9 \\
\hline \multirow{2}{*}{$\begin{array}{l}\text { C6: Long Career } \\
\text { with very high } \\
\text { earnings }\end{array}$} & $\begin{array}{c}1946 \\
N=1369\end{array}$ & $\begin{array}{c}26774 \\
(16836)\end{array}$ & 0.9 & 77.7 & $\begin{array}{c}20.4 \\
(20.0)\end{array}$ & 52.6 & 15.8 & 9.1 \\
\hline & $\begin{array}{c}1962 \\
N=1348\end{array}$ & $\begin{array}{c}37089 \\
(21529)\end{array}$ & 2.9 & 88.2 & $\begin{array}{c}18.5 \\
(17.4)\end{array}$ & 66.1 & 27.7 & 6.3 \\
\hline \multirow{2}{*}{$\begin{array}{l}\mathrm{C} 1 \text { : Long Career } \\
\text { with interruptions } \\
\text { and/or very low } \\
\text { earnings }\end{array}$} & $\begin{array}{c}1946 \\
N=3259\end{array}$ & $\begin{array}{c}9884 \\
(6975)\end{array}$ & 2.5 & 93.9 & $\begin{array}{c}20.7 \\
(17.7)\end{array}$ & 1.6 & 62.6 & 21.6 \\
\hline & $\begin{array}{c}1962 \\
N=4718\end{array}$ & $\begin{array}{c}12852 \\
(8864)\end{array}$ & 12.2 & 98.3 & $\begin{array}{c}18.3 \\
(14.5)\end{array}$ & 3.3 & 59.8 & 22.2 \\
\hline \multirow{2}{*}{$\begin{array}{l}\text { C11 : Very insecure } \\
\text { Careers }\end{array}$} & $\begin{array}{c}1946 \\
N=702\end{array}$ & $\begin{array}{c}4752 \\
(8318)\end{array}$ & 1.2 & 93.1 & $\begin{array}{c}20.3 \\
(16.5)\end{array}$ & 0.5 & 88.1 & 4.7 \\
\hline & $\begin{array}{c}1962 \\
N=976\end{array}$ & $\begin{array}{c}5900 \\
(10219)\end{array}$ & 0.4 & 92.5 & $\begin{array}{c}19.1 \\
(17.2)\end{array}$ & 1.1 & 92.5 & 4.6 \\
\hline \multirow{2}{*}{$\begin{array}{l}\text { C13: Short Careers } \\
\text { leading to inactivity }\end{array}$} & $\begin{array}{c}1946 \\
\mathrm{~N}=1874\end{array}$ & $\begin{array}{c}7511 \\
(46169)\end{array}$ & 2.0 & 90.2 & $\begin{array}{c}14.1 \\
(11.0)\end{array}$ & 8.7 & 75.1 & 12.4 \\
\hline & $\begin{array}{c}1962 \\
\mathrm{~N}=1518\end{array}$ & $\begin{array}{l}10905 \\
(9029)\end{array}$ & 9.6 & 94.2 & $\begin{array}{l}11.2 \\
(8.0)\end{array}$ & 2.7 & 59.7 & 7.2 \\
\hline \multirow{2}{*}{ Whole Population } & $\begin{array}{c}1946 \\
\mathrm{~N}=15099\end{array}$ & $\begin{array}{c}14365 \\
(16308)\end{array}$ & 1.5 & 83.4 & $\begin{array}{c}19.8 \\
(18.5)\end{array}$ & 7.5 & 49.3 & 100 \\
\hline & $\begin{array}{c}1962 \\
\mathrm{~N}=21313\end{array}$ & $\begin{array}{c}17638 \\
(13019)\end{array}$ & 6.1 & 90.4 & $\begin{array}{c}18.5 \\
(16.9)\end{array}$ & 9.1 & 49.9 & 100 \\
\hline
\end{tabular}

Source: Drees, EIC 2001 and calculations from Cnam-Inra-Agirc/Arrco.

Table 6: Earnings Equations by Typological Class for the 1946 and 1962 Generations

\begin{tabular}{|l|c|c|c|c|c|c|}
\hline \multirow{2}{*}{\multicolumn{1}{|c}{ Class }} & \multicolumn{3}{c|}{ 1946 Generation } & \multicolumn{3}{c|}{ 1962 Generation } \\
\cline { 2 - 7 } & Constant & Experience & Experience $^{2}$ & Constant & Experience $^{\text {Experience }}{ }^{2}$ \\
\hline C2: Long Career with very low earnings & & & & 9.06 & 0.104 & -0.004 \\
\hline C3: Long Career with low earnings & 7.48 & 0.165 & -0.003 & 8.93 & 0.103 & -0.003 \\
\hline C5: Long Career with high earnings & 8.03 & 0.177 & -0.007 & 9.27 & 0.104 & -0.003 \\
\hline C6: Long Career with very high earnings & 9.02 & 0.158 & -0.004 & 10.52 & 0.056 & -0.003 \\
\hline $\begin{array}{l}\text { C1: Long Career with interruptions and/or } \\
\text { very low earnings }\end{array}$ & 7.58 & 0.105 & -0.002 & 8.77 & 0.025 & 0.001 \\
\hline C11: Very insecure Careers & 6.05 & -0.076 & -0.006 & 8.54 & 0.080 & $\mathrm{~ns}$ \\
\hline C13: Short Careers leading to inactivity & 7.78 & 0.156 & -0.008 & 9.06 & 0.091 & -0.002 \\
\hline
\end{tabular}

Note: Within estimations. All regressions include year dummies (estimates not shown). All of the estimated coefficients are significant at the one per cent level, except those indicated by $n s$.

Source: Drees, EIC 2001 and calculations from Cnam-Inra-Agirc/Arrco. 
Figure 2: Long Careers with Very Low Earnings

1946: this class does not appear

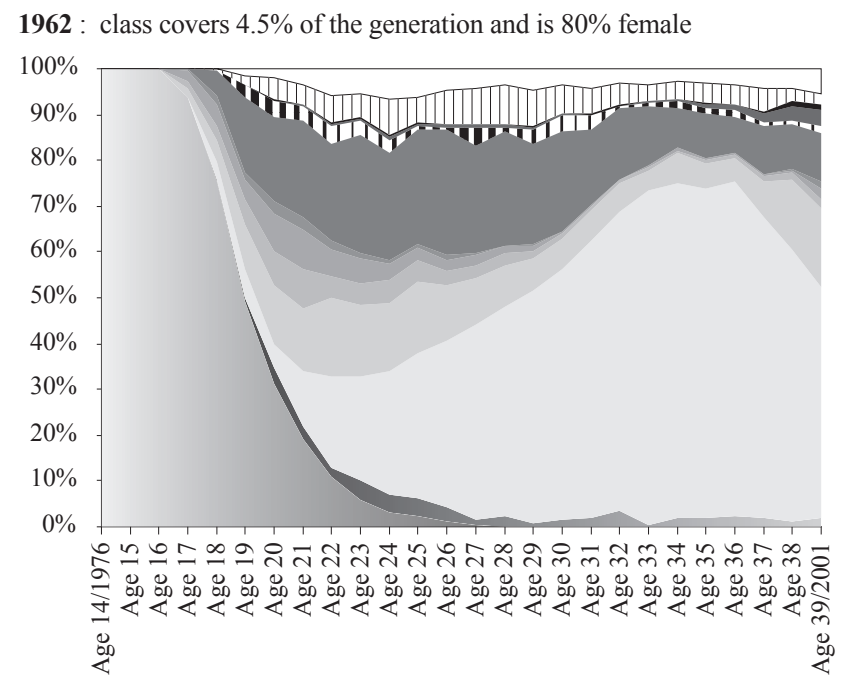

Source: Drees, EIC 2001 and calculations from Cnam-Inra-Agirc/Arrco.

\section{Figure 3: Long Careers with Low Earnings}

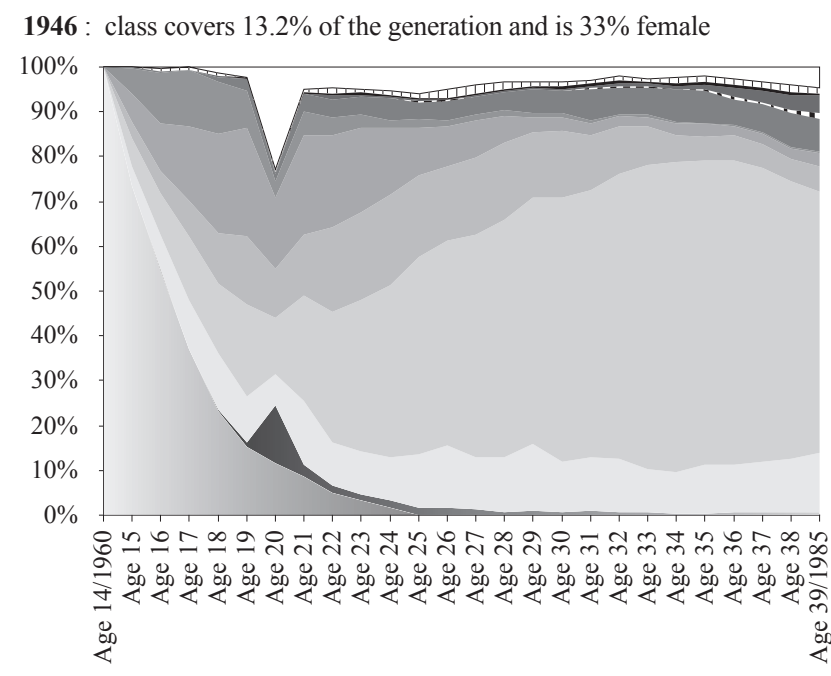

Source: Drees, EIC 2001 and calculations from Cnam-Inra-Agirc/Arrco.

distribution: see Figure 2). The wage equations in these two classes exhibit the classic features of this type of career: a low starting point and only slow earnings growth, in particular for the most recent generation.

In the new class, average annual gross earnings are 10703 Euros, which is a notably low figure for the 1962 generation. The percentage of workers in this class who have experienced career interruptions is particularly high in this class, with a figure that is very close to that of those in the insecure career class (see below). In class C3, which was already present in the 1946 generation, average annual gross earnings are 12717 Euros (1946 generation) and 15553 Euros (1962 generation). The percentage of managers is almost zero (see Table 5).

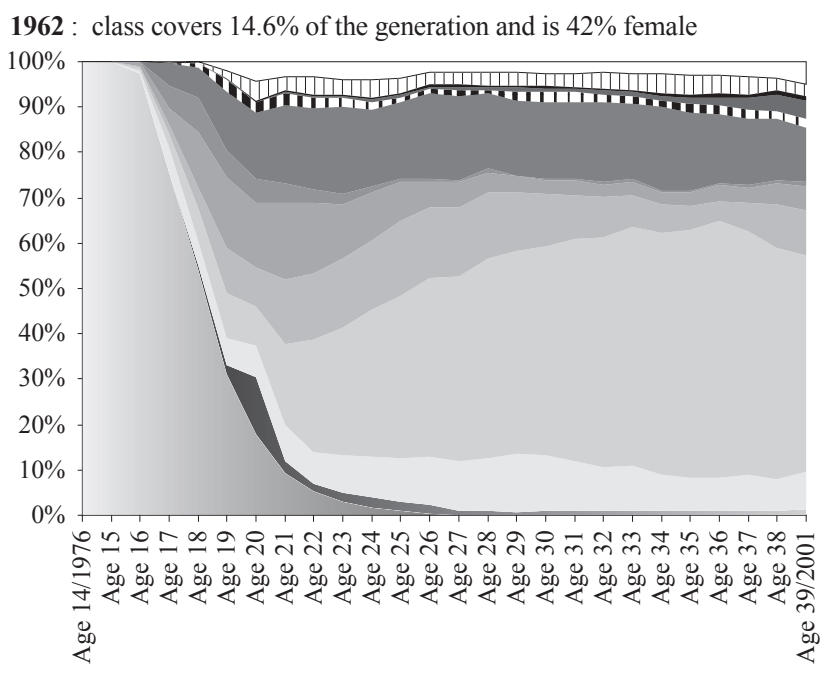

The male-female ratio is moving towards parity in the pre-existing low earnings class (C3): this class was made up of two-thirds men in the 1946 generation, which figure dropped to $54 \%$ in the 1962 generation. The percentage of women is particularly high in the new low earnings class (C2: see Table 5), to the extent that we could refer to this as a feminine class.

\section{The Change in Long Careers with High Earnings}

At the other end of salary scale we find long careers with high or very high earnings (between the $60^{\text {th }}$ and $85^{\text {th }}$ centiles of the earnings distribution and above the $85^{\text {th }}$ centile respectively), the share of which rises over time to reach just over one-fifth of the generation born in 1962. The wage equations 
show a steep growth in earnings for the 1946 generation, which drops off quite noticeably for those born in 1962. The average annual gross earnings figures are sharply different between these two classes: 18209 Euros (1946 generation) and 22787 Euros (1962 generation) for the high earners, with analogous figures of 26774 Euros and 37089 Euros for the very-high earners. Earnings growth is higher in the latter group. The two groups also differ in terms of managerial status: this is frequent $(52.6 \%$ and $66.1 \%$ ) for the very high earners but fairly rare $(1.9 \%$ and $9 \%)$ for high earners. However, the two groups are similar in terms of career stability: there are few career interruptions relative to other groups of workers, although their number does increase from one generation to the other (see Figures 4 and 5). The very high earners have lower levels of both experience and seniority, due to their later entry onto the labour market (respectively at the ages of 22 and 24). They thus have a priori higher levels of education. These two classes are therefore similar in terms of employment stability, even if this has become somewhat attenuated, but differ on some quantitative (earnings) and qualitative (manager) levels.

The share of women in both of these classes was only low in the 1946 generation. This share grows in the 1962 generation, but still remains significantly below the population figure. There is something of a gender convergence then, but which is slower as the level of earnings rises: the percentage of women is $31.2 \%$ for high earners but $27.7 \%$ among very high earners, which is consistent with the existence of a glass ceiling.

In general, the increasing share of high earners and the rising percentage of women among them is in line with the results of MulLigan and Rubinstein (2008). The latter compare the US situation in the 1975-1979 period to that in the 1995-1999 period, and show that the fall in the male-female wage gap is partly explained by increasing female wage inequality and the existence of high-wage women.

Figure 4: Long Careers with High Earnings
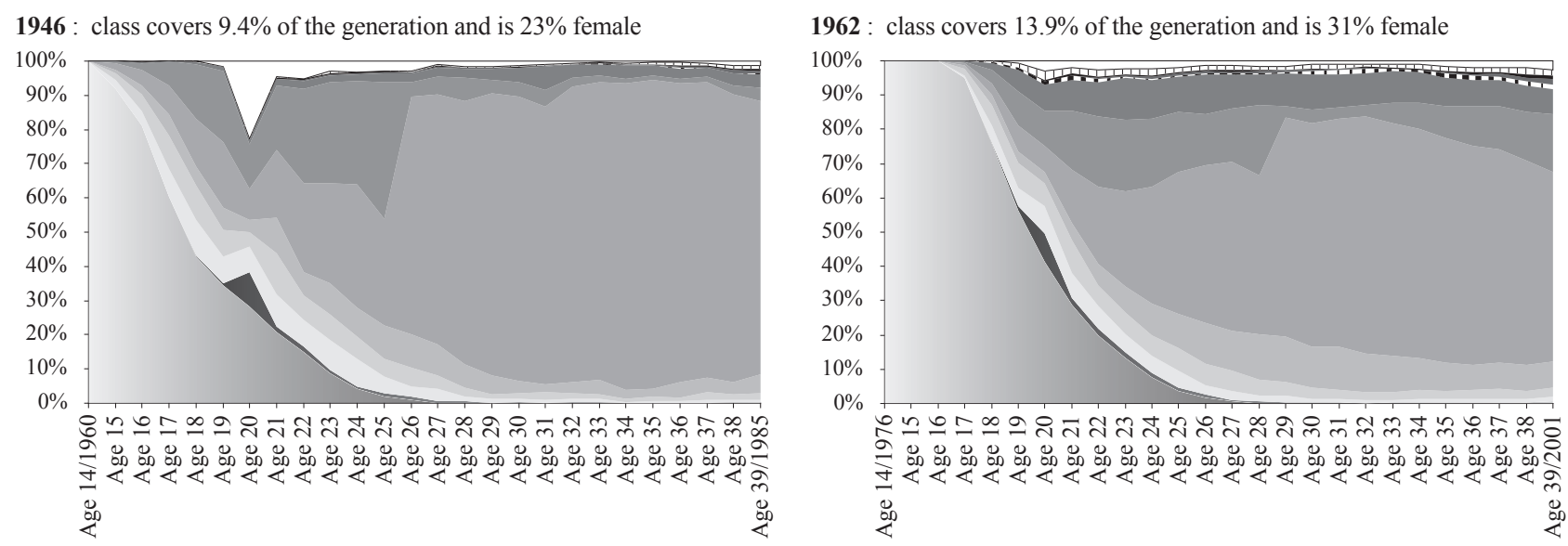

Source: Drees, EIC 2001 and calculations from Cnam-Inra-Agirc/Arrco.

Figure 5: Long Careers with Very High Earnings
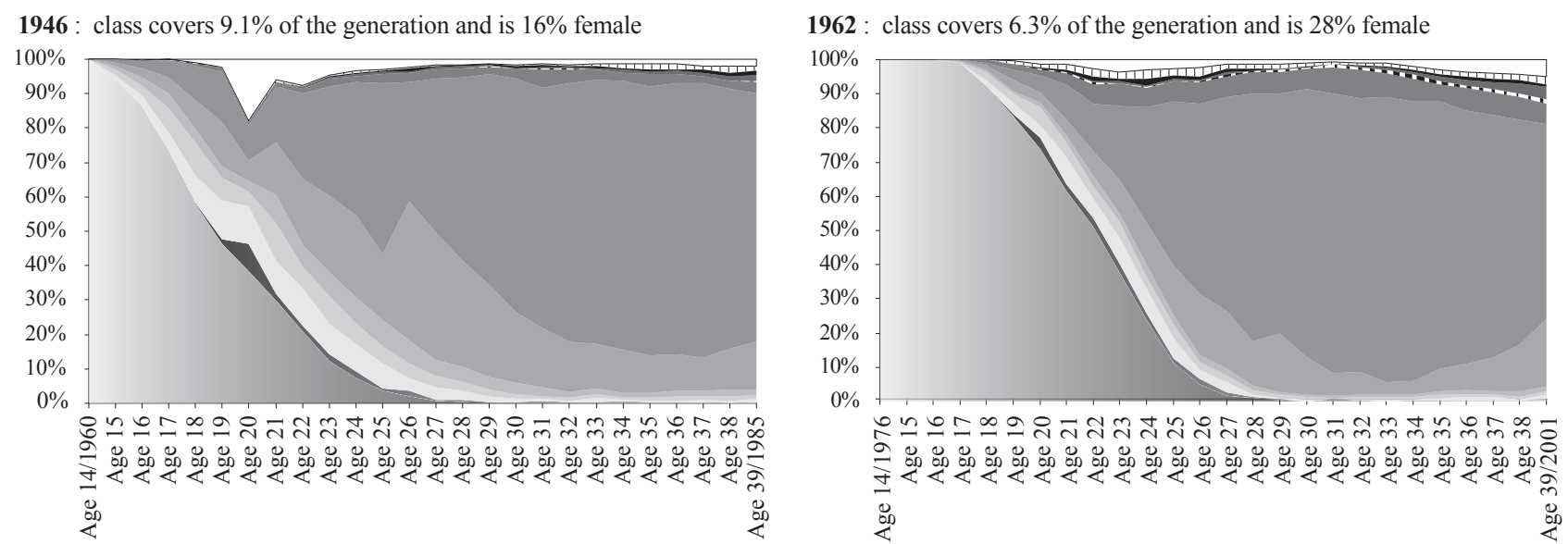

Source: Drees, EIC 2001 and calculations from Cnam-Inra-Agirc/Arrco. 
Figure 6: Long Careers with Interruptions and/or Very Low Earnings

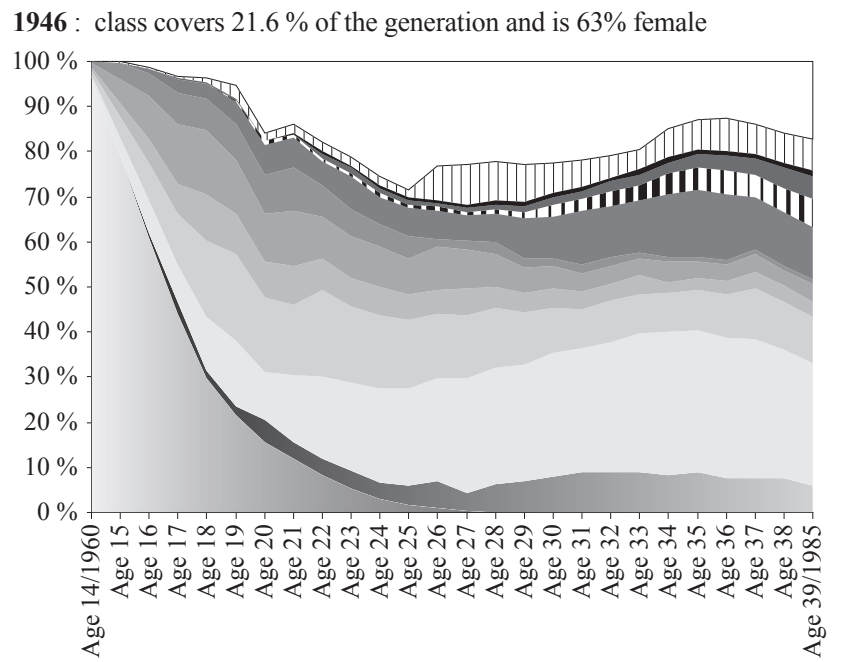

1962 : class covers $22.2 \%$ of the generation and is $60 \%$ female

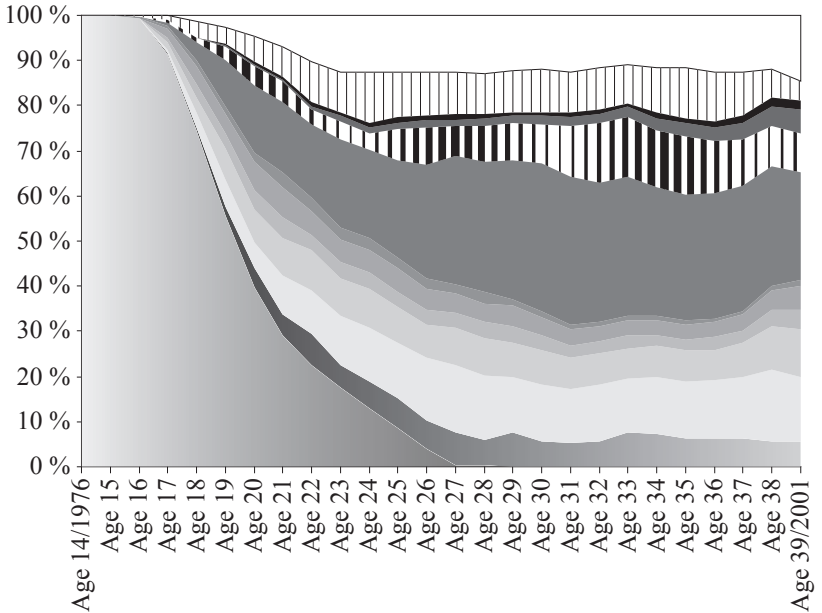

Source: Drees, EIC 2001 and calculations from Cnam-Inra-Agirc/Arrco.

Figure 7: Very Insecure Careers with Fewer than Four Validated Quarters

1946 : class covers $4.7 \%$ of the generation and is $88 \%$ female

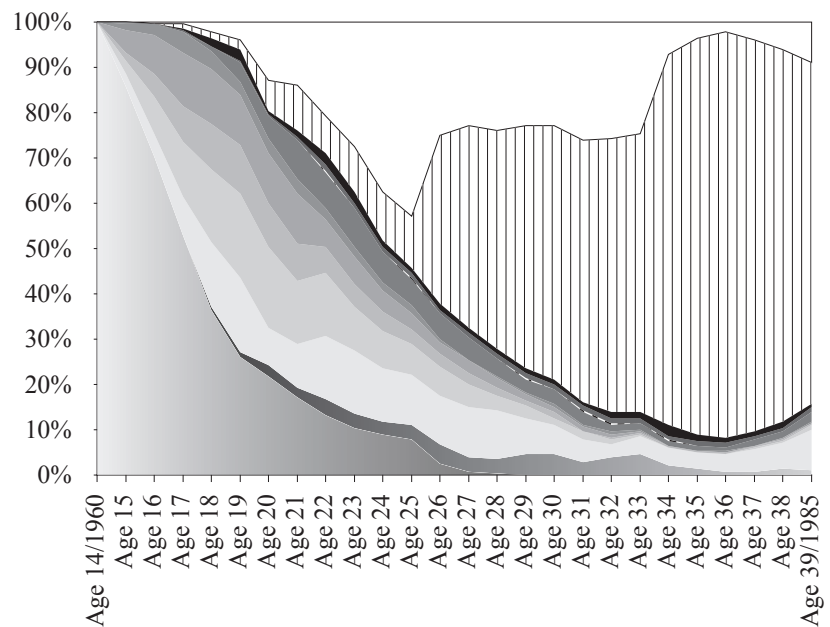

1962 : class covers $4.6 \%$ of the generation and is $93 \%$ female

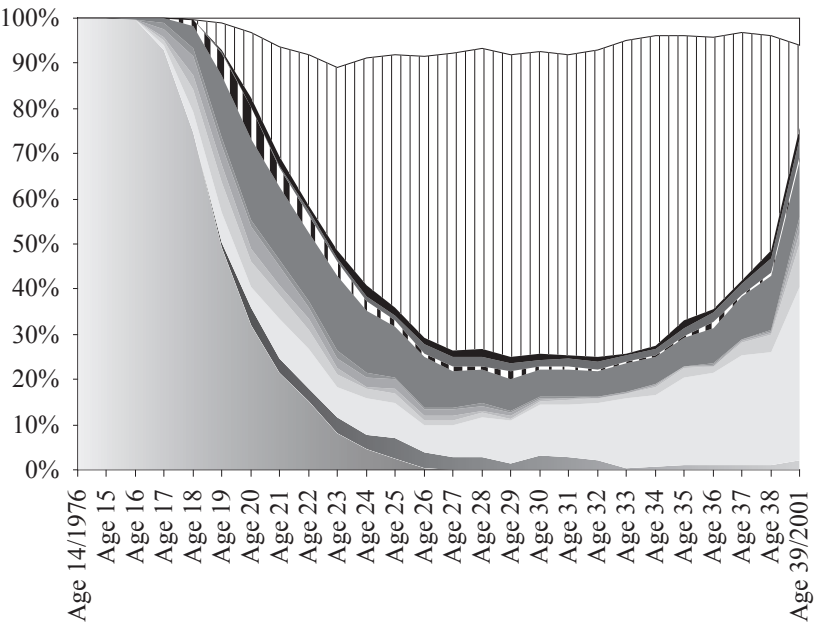

Source: Drees, EIC 2001 and calculations from Cnam-Inra-Agirc/Arrco.

Figure 8: Short Careers Leading to Inactivity

1946 : class covers $12.4 \%$ of the generation and is $75 \%$ female

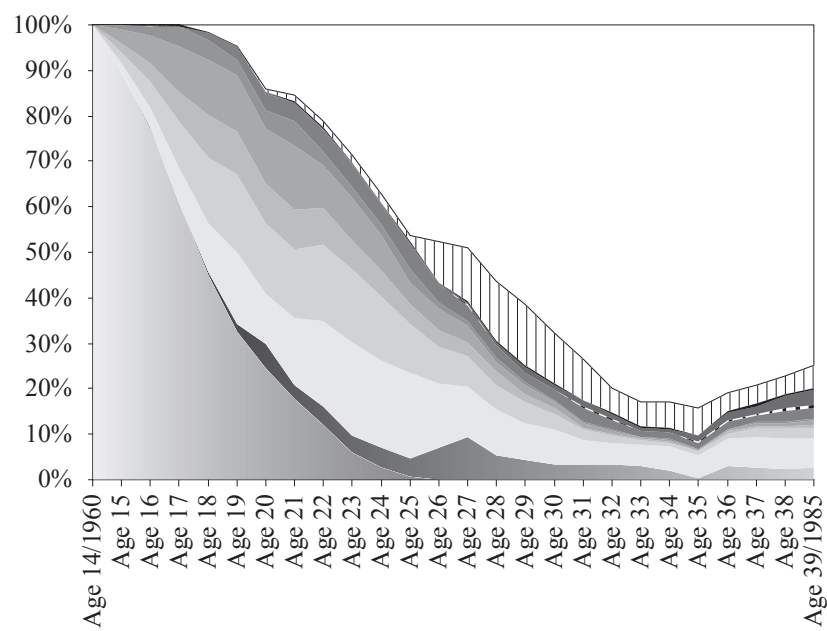

1962 : class covers $7.2 \%$ of the generation and is $60 \%$ female

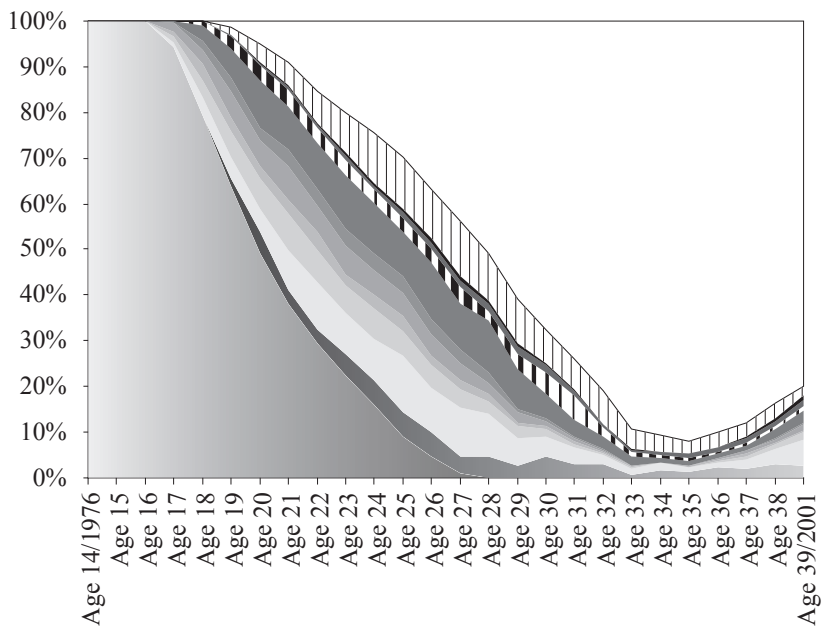

Source: Drees, EIC 2001 and calculations from Cnam-Inra-Agirc/Arrco. 


\section{The Growth/Persistence of Careers Marked by Different Forms of Insecurity}

Two classes of our typology, which are found in both the 1946 and 1962 generations, illustrate the growth in careers which are marked by different forms of insecurity. The first class (C1) consists of employees who have long careers in the private sector which are nonetheless characterised by career interruptions or very low earnings (see Figure 6). The percentage of individuals in this group was already quite substantial in the 1946 generation and became even more so in the 1962 generation. Almost one quarter of workers are found in this group. Starting from the 1946 generation, this class is typified by low levels of earnings and frequent career interruptions but without the link to the labour market being broken, nor the validation of four quarters of annual social-security contributions for retirement. Average annual gross earnings are low at 9884 and 12852 Euros respectively for the 1946 and 1962 generations, which is around half of the average population level. The wage equations here present classic features, which are somewhat attenuated in the 1962 generation. The incidence of career interruptions is remarkably high and grows over time to reach an annual level of over $12 \%$ of observations. We therefore logically see a rising gap between potential experience and effective seniority. The number of women found in this class has risen, but their percentage has fallen (although this class remains majority female). The mix of insecurity and low earnings, as captured in this class, thus continues to be a relatively female characteristic, although it does cover an increasingly large number of men. Insecurity is growing amongst workers, both in terms of the number of individuals concerned and the frequency of career interruptions.

The second insecure class (C11) is massively female (see Figure 7). Earnings in this group are extremely low: 4752 Euros and 5900 Euros in the 1946 and 1962 generations, which is only a third of the population average. Career interruptions in this group are however actually not exceptionally prevalent, and show no tendency to rise over time. Individuals have careers which develop at the margin of the labour market, with part-time or a succession of short-term jobs for example. Insecurity is reflected by the fact that individuals do not validate four quarters of social-security contributions for retirement. The wage equations for this group show that the standard model provides a very poor fit. This class of workers therefore represents a long-established group of almost exclusively female (nine out of ten) insecure workers.

\section{The Decline of the Classic Model of the Female Career of the 1950s and 1960s}

One of the classic models of the female career in the 1950s and 1960s, whereby women stopped working almost definitively after having children, has waned and transformed into other types of careers (see Figure 8). This classic model is prevalent in the 1946 generation, where we see labour-market withdrawal starting from age 25-26 followed by a slight return to work starting from age 35 . This mainly concerns women who left the labour market at a young age, suggesting withdrawal due to maternity and taking care of young children. Meurs et al. (2008) provide a detailed analysis of career interruptions linked to the presence of children on the labour-market careers of women.

This model is still found in the 1962 generation, but applies to fewer individuals $(7.2 \%$ of the population, as against $12.4 \%$ in 1946). The characteristics of individuals in this class also change significantly from one generation to the other. The wage equations suggest a much flatter career earnings profile for the 1962 generation. The percentage of managers in the 1946 generation, $8.7 \%$, falls to $2.7 \%$ in the 1962 generation. Average experience falls from the already low figure of 14.1 years in the 1946 generation to a figure of 11 years in the 1962 generation. Effective seniority follows the same path, falling from 11.2 to 8 years. Career interruptions are of course very frequent here, although they are of a particular type, concerning long and essentially irreversible moves into inactivity. At the same time as the model changes, so has its feminine character: the percentage of women in the class falls from $75.1 \%$ to $59.7 \%$. As such, men are increasingly found in this type of career, and very likely for reasons that are not linked with raising children. This is one last example of the convergence of labour-market careers between men and women, in a model that significantly differs from that found in the preceding generation.

The labour-market careers in the private sector of individuals of the 1946 and 1962 generations are profoundly different. The cleavage between male and female careers is a useful way of summarising the initial situation, that of the labour market in the 1960-1975 period. This cleavage is far less useful for more recent years. Wage equations suggest that the standard model of a career on an upward trend without any major discontinuities only holds for men of the 1946 generation; this model does only an imperfect job of describing female careers in this generation, and an even worse job regarding both male and female careers in the later generation. The 
increasing presence of career interruptions requires us to replace the classic measure of potential experience given by the date of labour-market entry by effective seniority.

The construction of a typology of individual careers has allowed us to considerably enrich our analysis. Almost one-third of workers have insecure careers on the labour market. This insecurity can take on a number of different forms: frequent career interruptions which may produce low wages, or under-employment, with a permanent but only loose relationship to the labour market. Taking these various situations into account allows us to provide further detail on the difference between male and female labour-market careers. The first form always consists of a majority of women, although it now covers an increasing number of men as well. The second, which was already present in the 1946 generation is almost exclusively female. Careers with low (very low) and high (very high) earnings continue to represent clearly-defined separate labour-market careers. The relationship between the percentage of women in the class and the level of earnings is almost monotonic. Even so, it should be underlined that all classes are now characterised by an increasing number of career interruptions. Last, certain types of "female" careers, such as labour market activity which is cut short by the presence of children, have become both less prevalent on the labour market and less female over time.

We conclude that there has indeed been a convergence between male and female careers on the labour market. This convergence has been towards a new career model which is likely closer to the initial situation of women in the early generation than that of men. The key characteristics of these new careers seem to be the growing presence of insecurity and interruptions, with the preservation of a wide distribution of earnings, where average earnings in a class are lower the higher is the percentage of women found there.

\section{Bibliography}

Amossé T., Ben Halima M. A. (2010), «Mobilité et stabilité sur le marché du travail: une dualisation en trompe-l'oeil» Connaissance de l'emploi, le Quatre Pages du CEE n 75, décembre.

Behaghel L. (2003), «Insécurité de l'emploi : le rôle protecteur de l'ancienneté a-t-il baissé en France? », Économie et Statistique n ${ }^{\circ} 348$, pp. 61-79.

Behaghel L. (2006), Lire l'économétrie, édition La Découverte.

Berton F, Huiban J.-P., Nortier F. (2009), «Génération 1946 versus génération 1962 : vers des carrières salariales plus discontinues» in Barnay T. \& Legendre F. (dir) «Emploi et politiques sociales, trajectoires d'emploi et rémunérations », L'Harmattan, tome 2, pp. 7-21

Briard K. (2007), «Profils-type des salariés du secteur privé : approche par une classification des carrières», Economie et Prévision n ${ }^{\circ} 180-181,2007 / 4-5$, pp. 59-85.

Buchinsky M., Fougère D., Kramarz F. (1998), «La mobilité salariale en France: 1967-1987», Revue Économique vol 49 n ${ }^{\circ}$ 3, pp. 879-890.

CARD D. (1999), "The causal effect of education on earnings", in Ashenfelter O. and Layard R. eds. Handbook of Labor Economics, vol. 3, North Holland.

Colin C., El Mekkaoui de Freitas N., Michaudon H. (2004), «Comment mesurer les droits acquis à la retraite en France: la création de l'Échantillon Interrégimes de Cotisants», Courrier des Statistiques $\mathrm{n}^{\circ} 111$, septembre, pp. 19-29.
Cornwell C., Rupert, P. (1988), "Efficient Estimation with Panel data: an empirical comparison of instrumental Variables estimators", Journal of Applied Econometrics n 3, pp. 149-155.

Debrand T., Privat A. G. (2002), «L'évolution des carrières salariales au cours des cinquante dernières années », Retraite et Société n 36, pp. 188-201.

Demailly D., Le Minez S. (1999), «Les salariés à temps complet au voisinage du Smic de 1976 à 1996», INSEE, Insee Première, $\mathrm{n}^{\circ} 642$.

Givord P., MAURIN E. (2003), «La montée de l'instabilité professionnelle et ses causes», Revue économique, vol. $54 \mathrm{n}^{\circ} 3$, pp. 617-626.

GrelEt Y., (2002), «Des typologies de parcours méthodes et usages », Céreq, Notes de travail génération $92 \mathrm{n}^{\circ} 20$, juillet, $47 \mathrm{p}$.

Hausman J. A., TAYlor W. (1981), "Panel data and unobservable individual effects", Econometrica, n ${ }^{\circ} 46$, pp. 1377-1399.

De Larquier G., Remillon D. (2008), «Assiste-t-on à une transformation uniforme des carrières professionnelles vers plus de mobilité? ", Travail et Emploi $\mathrm{n}^{\circ} 113$, janvier-mars, pp. 13-30.

LeClair M., Roux S. (2006), «Les emplois de courte durée dans les entreprises», Données Sociales. La société française, pp. 25-253.

Leclair M., Roux S. (2007), «Productivité relative et utilisation des emplois de courte durée dans les 
entreprises», Économie et Statistique, $\mathrm{n}^{\circ}$ 405/406, pp. 47-76.

Lollivier S., Payen J.-F. (1990), «L'hétérogénéité des carrières individuelles mesurée sur données de panel», Économie et Prévision $\mathrm{n}^{\circ}$ 92-93, pp. 87-95.

Magnac T., Roux S. (2009), «Dynamique des salaires dans une cohorte», Economie et Prévision, n ${ }^{\circ}$, pp. 1-24.

Meurs D., Ponthieux S. (2006), «L'écart des salaires entre les hommes et les femmes peut-il encore baisser? », Économie et Statistique n 398-399, pp. 99-129.

Meurs, D., Pailhe A., Ponthieux, S., (2008), "How much does it cost to stay at home? Career interruptions and the gender wage gap in France", Document de travail INSEE F0802.
Mincer J. (1974), Schooling, Experience and Earnings, Columbia University Press, New-York.

Mulligan C. B., Rubinstein Y. (2008), "Selection, Investment, and Women's relative wages over time", Quarterly Journal of Economics, ${ }^{\circ} 3$, pp. 1061-1110.

NAKache J.-P., Confais J. (2005), Approche pragmatique de la classification, Technip, $256 \mathrm{p}$.

Nortier F., Rass C. (2006), «Les carrières s'aplatissent», Dossier Retraités et retraite 2005-2025, Retraite complémentaire AGIRC-ARRCO, $1^{\text {er }}$ trim., 20 p.

WiLlis R. G. (1986), "Wage Determinants: a Survey and Reinterpretation of Human Capital Earning Functions", in Ashenfelter O. and Layard R. eds. Handbook of Labor Economics, North Holland. 